instrument mentioned the pages on which descriptions of such instruments will be found. Some of the illustrations are not very informative, while others show internal details by cutting away enclosures, and a few give wiring diagrams.

\section{Archæological Investigations in Turkey}

A REPORT of results of the continued excavations of the Neilson Expedition to Turkey of the University of Liverpool on the site at Mersin in Southern Turkey, records the discovery of the remains of a fortified city, of which the architectural structure is remarkable (The Times, January 3). The gateway is flanked by towers; and a defensive wall is pierced by a range of narrow windows. Piles of improvised missiles lie at hand. The whole city was destroyed by fire while still in occupation; and the contents of the buildings, which include a palace, are said to be complete, though much burned by fire and broken. These remains were encountered at a depth of twenty feet below those of the Hittite city brought to light by the expedition last year. They are assigned to a date at about 3600 B.c.

\section{Earthquake near Japan}

The U.S. Coast and Geodetic Survey, in cooperation with Science Service and the Jesuit Seismological Association, has made a preliminary determination of the epicentre of the earthquake of November $22,1938,1$ h. $14 \cdot 1$ m. G.C.T., and finds it to be situated in latitude $37^{\circ} \mathrm{N}$., longitude $142^{\circ} \mathrm{E}$. This was made possible by reports from the seismological stations at Honolulu, Manila, Zikawei, Victoria, Georgetown, Fordham, Sitka and Philadelphia. This epicentre is under the bed of the ocean to the northeast of the main island of Japan, and is near the epicentres of the shocks of November 5 and 6 , which were lat. $38^{\circ} \mathrm{N}$., long. $141^{\circ} \mathrm{E}$., and lat. $36^{\circ} \mathrm{N}$., long. $144^{\circ} \mathrm{E}$. respectively.

\section{Earthquake in Belgium}

THERE was an earthquake during the evening of December 30, with epicentre in the vicinity of Spixhe, near Spa, which caused the collapse of chimneys and moved furniture but caused no casualties. This recalls the earthquake of June 11, 1938, which probably had an epicentre somewhat to the north-west of the present one, and was felt in England, France, and Germany as well as in Belgium (Nature, 141, $1090 ; 1938)$. The other epicentre near the present one was located in the International Seismological Summary as lat. $5 \mathrm{l}^{\circ} \mathrm{N}$., long. $6^{\circ} \mathrm{E}$., which is to the north-north-east of the Spixhe shock and just inside the borders of Germany. Earthquakes occurred from the German epicentre on January 5, 1926, and January 14, 1928.

\section{Announcements}

WE regret to announce the deaths of Mr. Emile Mond, honorary treasurer of the Chemical Society and of the Faraday Society, on January 1, aged seventy-three years; and of Prof. Victor Grégoire, professor of botany in the University of Louvain, on December 12, aged sixty-eight years.
Prof. Ejnar Hertzsprung, director of the Observatory and professor of astrophysics in the University of Leyden, has been elected correspondant of the Section of Astronomy of the Paris Academy of Sciences in succession to the late Dr. W. W. Campbell.

Among the recent medal awards of the Royal Horticultural Society are the following: Victoria Medal of Honour to Dr. W. F. Bewley, Mr. H. R. Darlington, Mr. F. G. Preston, and Mr. G. Reuthe ; Veitch Memorial Gold Medals to Mr. M. B. Crane and Miss I. Preston.

A CENTRE for aeronautical studies and research has recently been founded at Milan by the Italian Ministry of Aeronautics.

TнE University of Porto Alegre, with the support of the Federal Government of Brazil, has decided to erect a hospital including a pathological institute.

The Cornell University Medical College, New York, has received from the Jane Coffin Childs Fund for Medical Research the sum of 4,500 dollars for experimental investigations of leukæmia with special reference to extra-chromosomal factors. The research will be carried out by Drs. C. L. Opie and J. Furth, of the Department of Pathology.

The Government Health Service of the Dutch East Indies has instituted an investigation among medical practitioners as to their experience with medicinal plants. This will be carried on at the same time that the Commission on the Commerce of Medicinal Herbs is conducting a botanical and pharmacological analysis and a series of technical experiments in the cultivation of such plants.

The Hellenic Travellers' Club has arranged a tour on March 18-April 7 to sites of medical interest in Greece. At Epidaurus, Prof. G. E. Gask will lecture on the cult of Asculapius, and visits will also be paid to Cos, where the school of Hippocrates flourished, Cnidos, Pergamos, the home of the school of Galen, Athens and Mycenæ. Further information can be had from the Secretary, 3 Albany Courtyard, Piccadilly, W.1.

The Royal Academy of Sciences of Turin announces that the thirty-first award of the Bressa Foundation Prize will be made during 1941. The prize, of the value of 9,000 lire, will be awarded to the man of science, either Italian or foreign, who, in the opinion of the Academy, shall have made the most notable and useful discovery or produced the most important work during the period 1937-41 in any of the following branches of science: physical and experimental science, natural sciences, pure and applied mathematics, chemistry, physiology, pathology, geology, history, geography and statistics. Authors who wish to have their work considered are invited to send copies, which must be printed, to the secretary of the Academy, Via Maria Vittorio 3, Turin, not later than January 31, 1941. 